\title{
Unholy Union: History, Politics and the Relationship between Church and State in Modern France
}

\author{
Herman T. Salton ${ }^{1}$ \\ ${ }^{1}$ Department of International Politics, University of Wales, Aberystwyth, UK \\ Correspondence: Herman Salton, Department of International Politics, Room 3.25, University of Wales, Penglais \\ Campus, Aberystwyth SY23 3FE, UK. Tel: 44-1970-621-610. E-mail: hes3@aber.ac.uk
}

Received: September 8, 2012

Accepted: October 8, 2012 Online Published: October 29, 2012

doi:10.5539/res.v4n5p135

URL: http://dx.doi.org/10.5539/res.v4n5p135

\begin{abstract}
Few countries have had such a complex, conflictual and contradictory relationship with religion as France. This article reassesses the key literature on the subject and argues that while the place of religion in French history remains as controversial and as difficult to define as ever, the country's coming of age actually occurred in 1905 with the law of separation between Church and State. This article also suggests that while France remains predominantly Catholic at heart, a key ingredient of national identity lies in the revered principle of laïcité, and this has in fact emerged out of fierce struggles with the Catholic Church.
\end{abstract}

Keywords: laïcité, secularism, founding fathers, religion, French politics, church and state

\section{Introduction: France, Religion and the Union of Church and State}

Long-considered 'the eldest daughter of the Church' because of the spiritual fervour of its people and the determination of its governments to act as the 'secular arm' of Catholicism, France has also witnessed some of the most virulent anti-Catholic and anti-religious episodes in Europe, episodes that have caused civil war and brought the country perilously close to self-destruction.

The interwoven relationship between Church and State has a long history both in France and among her European neighbours, and the apex of this synthesis was reached when kings were directly invested with the sacred mission of expressing the will of God and "managing the earthly world" on His behalf (Charlier-Dagras, 2002: 17). Yet France does seem to stand out from the European crowd in one key respect. Throughout history, the State has exhibited extreme shifts in its relationship with the Catholic Church, at times being openly in favour of the religion, and at others being in strong opposition to it. This unstable and ambiguous relationship has divided the Nation and it goes some way to explaining why religion is seen to be so intensely divisive in the Country, in comparison to the widespread understanding of the unifying capacity of the République (Note 1).

This is partly the result of the fiercely anti-clerical character of the French Enlightenment. As one author has pointed out, "neither the English Enlightenment nor the German Aufklärung have undertaken to fight against the Church with a stubbornness similar to that of the French lumières" (Ormières, 2002: 215). Yet there is more to it than this. Opposition to the Catholic Church in France translated into a broader hostility towards religion tout court, and the apex of these feelings was reached in the years of the Great Terror that followed the 1789 Revolution. During this period churches were destroyed, sacred symbols were vandalized and a significant number of priests were killed. "One of the first consequences of the French Revolution", De Tocqueville commented, "was its attack on the Church and among the passions that resulted from this Revolution, the first one to have been lit and the last one to go out was the irreligious passion" (De Tocqueville, 1967: 62).

This contribution sees the relationship between France and the Catholic Church as a $15^{\text {th }}$ century-long marriage of convenience; a marriage characterized by jealousy, open betrayal, temporary separation and even physical confrontation. The significance of this tumultuous coupling - which was symbolically conceived as early as 496 with the Clovis baptize, and which only came to its acrimonious end in 1905 when France passed the law of separation between Church and State-is difficult to overstate. In some ways, France has never fully recovered from its turbulent relationship with the Catholic Church, and the country's confidence in religion has arguably been eroded. 
This article will highlight the crucial chapters of this extended liaison, and it will explore the genesis of the divorce and the consequent origin of the French idea of laïcite (Note 2). It will suggest that, in France, a persistent and almost congenital union between Church and State not only caused widespread death and persecution, but also produced three fateful and prolonged consequences: the weakening of the Church, the weakening of the State and, perhaps more tragically, the weakening of spirituality in general.

\section{The Union of Church and State in Early France}

\subsection{Church and State in Early-Europe (313 AD - 476 AD)}

Because early France was part of the Roman Empire, the initial phases of French religious history coincided with those of Europe, and on the Old Continent religion and politics were intimately connected (Goubert, 1984: 13-37; Miquel, 1976: 38). Although the Roman Emperor was already the object of sacred veneration and those Christians who refused to recognise this were persecuted, the crucial turning point in terms of a proper (if still unofficial) union between Church and State in Europe was 313, when Emperor Constantine-who called himself "emperor and theologian, king and priest" (Scot, 2005: 27) - converted to Christianity. The self-proclaimed 'universal bishop' convened religious councils to resolve theological issues. One such council, for example, was assembled in Nicaea in 325 because Constantine wanted "to establish true and sincere doctrine in the Church of Christ, with a settled purpose utterly to root out all false and heretical fantasies and opinion" (Lambert, 2003: 25) From that moment on, "nature and grace, law and Gospel, Church and State were confounded together" (Lambert, 2003: 25), and it would take one and a half millennia to disentangle them.

Important as the Nicaea Council had been, it was only when Constantine left Rome and founded Constantinople (or Byzantium) that the idea of Rome as an independent, spiritual entity separated from the Empire and headed by a pope started to emerge. In 343 the Sardinia Council took a decisive step in this direction when it decided that all bishops deposed by their local synods could appeal to the Bishop of Rome (the Pope), thereby recognising for the first time his primacy in spiritual affairs. Soon afterwards, Pope Damasius spoke of Rome as the "apostolic hub", and in 380 he pushed Emperor Theodosius to make Christianity the only official religion of the land, thus transforming it into a form of political domination (Note 3).

While subsequent popes consolidated their centralized power by writing decretales (official answers to theological questions), the Roman Empire itself was collapsing into chaos and the Church came increasingly to be seen as the only organized structure capable of survival. And survive it did, partly thanks to its bishops-who were ready to negotiate with the barbarian invaders in order to save their territories - and partly thanks to Pope Leon I and his Rome-saving peace talks with the Huns and Vandals. The Church emerged even stronger from these events and it was established that popes would have both increased temporal powers and the support of the Emperor in the future. As it turned out, however, this arrangement was to prove fragile and it soon became a source of conflict between the temporal and the spiritual authorities.

\subsection{The Union of Church and State in Early France}

\section{(i) The 'Birth' of France and the Formal Union with the Church}

The disintegration of the Roman Empire in 476 contributed to the birth of the French kingdom and to its union with the Church. In 481 King Louis I (Clovis) ascended to the throne and he promised to convert to Christianity after attributing what he percieved to be a miraculous victory in battle to the advice given by the Bishop of Reims (Rémi). "First and foremost", the clergyman had written to the King, "ensure that God does not leave you. Then ask your bishops for advice, for if you march in agreement with them, the land submitted to your authority will be better managed" (Pena-Ruiz, 2005: 34). The King won the battle and was baptized by Rémi during a solemn ceremony on Christmas day of 496. "Humbly bow your head", the clergyman ordered the King with a formula that acquired a significance of its own. Clovis thus became King of the Francs "for grace of God and the holy oils" and managed, in the following years, to reunite the various provinces of Gallia under both the Francs and Christian flags (Pena-Ruiz, 2005: 34). The rule of 'un roi, une foi, une loi' (in the Latin formula, cuius regio, eius religio) that Constantine had inaugurated in Europe two centuries earlier thus found its equivalent in France from the very early days of the Nation.

The centuries which followed would not only demonstrate how close but also how problematic this relationship between Church and State was. On the one hand the King, sacred in Reims, was God on Earth; he was inviolable and received his mandate from Him. On the other hand, God spoke through the Church and it was a clergyman who consecrated the King, thereby effectively limiting his authority. The result of this equilibrium was a highly hierarchical, theocratic society—omni potestas a Deo, 'all powers from God', the maxim went - and the clergy played a pivotal function that was simultaneously spiritual and temporal. "God has reserved to the clergy the 
most important role among the various social orders", one author wrote, "that of ensuring their cohesion and, if necessary, of eradicating the corrupting germs" (Miquel, 1980: 8). From the start, therefore, clergymen were not only in charge of the souls of the faithful, but also of maintaining the status quo because, in this hierarchical context, "those who want to change society offend God" (Miquel, 1980: 8). Indeed, the Church was certainly not shy in exercising its power, a power that according to one observer "not even the King could limit. How could he, after all, given that his own authority had been created by the clergy? They consecrated and buried the King. It is before them that oaths were performed, treaties signed and unions broken. It was impossible to live, marry or even die without them" (Miquel, 1980: 8).

In this context, feudalism - the system in which members of the lowest stratum of society were afforded protection and given land to labour by those of a higher rank, working and fighting for them in return return - proved profitable for the Church and instrumental in augmenting its temporal power. Not only was the vassal's fidelity based on the Bible, the feudal landowner was often himself a clergyman. As Professor Goubert observes, "the prestige of the Pope is immense but distant. The real chiefs of the French Church are the bishops...who more often than not come from powerful and noble families and have feudal connections" (Goubert, 1984: 23). Indeed, the Church was so prosperous that it became the biggest property owner in the French Kingdom, commanding "three-fourths of temporal ownership", according to the procurateur général in Paris, and its financial cortunes were estimated at two fifths of those of the state (Miquel, 1980: 34).

(ii) The Crusades (1095 AD - 1291 AD)

Important as they were, political influence and financial wealth would have had little impact without the third crucial asset of the Church: control over the faithful, which whilst spiritual in theory was, in fact, secular in practice. It was this control that allowed the institution to become so powerful as to be able to organize an army of devoted Christians with the direct support of the Francs kings between the $11^{\text {th }}$ and the $13^{\text {th }}$ centuries.

In 1095, Pope Urbanus II climbed on a podium in the city of Clermont and called for a 'crusade' (or 'holy war') to be waged in the name of the Christian cross. With the aim of regaining control over the sacred city of Jerusalem, the Pope encouraged men from France and throughout Europe to join the venture and fight against Muslims in a war that was initiated "under the direct guidance of God" (Baigent \& Leigh, 2004: 19). According to the Pope, killing in such an enterprise would have "ensured God's favour and a place beside His throne" and would have guaranteed exemption from all sins and crimes committed by participants (Baigent \& Leigh, 2004: 18). The Pope had the enthusiastic support of King Louis VII, a self-proclaimed 'pious' man who directed the first crusade and established the Francs kingdom of Jerusalem.

The Crusades numbered seven in total, spanned two hundred years (1095-1291) and remain to this day a symbol of the Church's influence over temporal affairs, and over France. As one author noted, "enough sanctity had accumulated in France by the $13^{\text {th }}$ century for a pope to concede that France was a "Holy Kingdom" and that "he who carries a war against the King of France works against the whole Church, against Catholic doctrine, against Holiness, Justice and the Holy Land" (Van Kley, 1996, 18-19).

\section{(iii) The Cathars Rebellion (1207 AD)}

However, the influence of the Church on French affairs was not confined to the realm of foreign policy. After the strategically unsuccessful, but religiously unifying experience in the Middle East, it was not long before the Pope encouraged internal crusades against his enemies and in this venture, too, France turned out to be a faithful ally (Sumption, 1978: 3). In 1207, Pope Innocent III wrote to the King and nobles of France, urging them to crush the Cathars heretics in the South of their country through military force. As a reward, His Holiness promised that he would grant them ownership of all confiscated lands', exemption from interest debts, immunity from secular justice and absolution from all sins. His wishes were soon answered and an army of almost twenty thousand men-headed by the papal envoy and French abbot Arnald-Amaury together with other French nobles and knights - was sent to suppress the rebellion. They left Paris with the express licence to "ransack, depredate and expropriate private property" and in the South, several thousand 'heretics' were burned alive (Baigent \& Leigh, 2004: 28). Questioned on how it was possible to distinguish the renegades from those faithful to the Pope, Abbot Arnald-Amaury notoriously replied: "Kill them all. God will recognise his own folks" (Baigent \& Leigh, 2004: 29). Fifteen thousand people were massacred, among them women and children: "None has been spared", the Abbot wrote to the Pope, "neither on the basis of age nor sex nor social position" (Baigent \& Leigh, 2004: 29).

The Cathars rebellion was crushed for good in 1224 during another joint expedition, this time headed by the King of France himself alongside the papal emissary. The Church-State union was healthier than ever, and had once again translated into religious repression. 


\subsection{Seeds of Disagreement}

\section{(i) French Gallicanism}

Such an accumulation of wealth and influence by an institution that was supposed to be spiritual could not avoid tension with the temporal power - especially because it inflamed an old controversy intrinsic to this very union (Sutherland, 1984). Given that it was the Pope who had consecrated the King, was not the former hierarchically superior to the latter?

The view of the religious authorities was clear. Already in the $11^{\text {th }}$ century, Pope Gregory VII had written in his Dictatus Papae that only the Bishop of Rome had the power to nominate the clergy and depose emperors. Furious, King Henry IV assembled a council of bishops and had the Pope removed, before being in turn excommunicated. The Church was clearly unhappy with a merely spiritual role: "There are two kinds of weapons", Pope Gelasius I declared, "the spiritual and the secular. Both belong to the Church, yet while the first is handled directly by her via the Pope, the second is handled indirectly via the kings, but only to the extent that the Pope so desires" (Scot, 2005: 27).

This rigid attitude irritated French kings and was instrumental to the birth of Gallicanism, a condition of self-professed temporal independence of the French monarchy from any other authority, and particularly from the Pope. According to the main theoretician of Gallicanism, Pierre Pithou, this tradition originally claimed that "popes cannot command or order anything that relates to the temporal power" (Charlier-Dagras, 2002: 18). In addition, "although the Pope is sovereign when it comes to spirituality, in France the absolute power belongs to the King" and, as a result, "all orders from Rome must be examined and received by the French Parliament before being declared admissible in the French Kingdom" (Charlier-Dagras, 2002: 18).

The Gallican movement dates back to the $10^{\text {th }}$ century, but gained prominence in 1297 when the then King of France, Philip the Handsome, declared that "he regarded his royal titles as deriving directly from God" (Autrand, 1974: 27). Although Pope Bonifacius VIII immediately reminded him that popes were superior to emperors, because the former were elevated to their position "by divine election" with an act that was "above kings and kingdoms", Phillip managed to rally the Nation behind what he defined as "the doctrine of absolute independence of the royal power" (Scot, 2005: 30). Duly excommunicated, he called a general council of the Church that put the Pope under accusation for abuse of power (Royer, 1969: 342).

Gallicanism proved to be hugely problematic to the hierarchically-oriented Catholic Church. It included the idea of the Council's superiority over the Pope, it proposed a close relationship between King and national clergy, and it affirmed the King's right to approve all papal legislation before it was applied in France, as well as his right to legislate on the administration of the French clergy. Although the latter was initially reluctant, these measures were ultimately accepted and Gallicanism was institutionalized in the $17^{\text {th }}$ century, when the Declaration of the French Clergy established that the country's Church is "an integral part of the French State." "The Pope and the Church", Article 1 read, "only have power over spiritual matters and not over material things", while Article 3 made it clear that "the rules, habits and constitutions in use within the Gallican Kingdom and Church must have their own force and virtue" (Charlier-Dagras, 2002: 18).

While Gallicanism played a crucial role in the emergence of the French idea of laïcité, it is important to note that the two experiences do not coincide. Although the Pope's function in temporal affairs was being limited, there was no formal divorce from the Church and the latter continued to retain general competence in spiritual matters. Moreover, since the King acted under direct guidance from God, French historian Jacques Le Goff observed that Gallicanism simply consisted of "a transfer of saintliness from the Church to the State" (Le Goff, 1996: 784) and can be understood as the French version of the Reformation - similar to Protestantism and Anglicanism but without a formal divorce of the kingdom from Rome (Note 4). Because it interposed itself between the State and the Pope, however, Gallicanism would eventually prove fatal to the French marriage of Church and State.

\section{(ii) The Reformation}

Gallicanism was not the only problem facing the Church. Beginning in the $16^{\text {th }}$ century, the forays of the latter into civil governance were increasingly contested in France, as were the exorbitant ecclesiastic tithes it collected. Particularly abhorrent to some observers was the commerce of indulgences, a custom that consisted of asking the faithful to pay money in exchange for the spiritual redemption of their sins (Scot, 2003: 31). This angered the poor and favoured the rich to an extent that "it was possible to buy paradise: for the bourgeoisie, faith was a certainty and religious practice mere accountancy" (Miquel, 1976: 39). In this way the Church lost the esteem of part of the population and came to "inspire profound disgust and a desire for purity" (Miquel, 1976: 157). This feeling eventually translated into the Protestant Reformation (Delumeau, 1988; Kingdon, 1956). 
In 1509 Erasmus published an essay that denounced precisely these abuses and called for "the eviction of the 'princes' ... and their 'culpable excesses"'. A few years later, Luther openly contested the authority of Rome and wrote that since "the only thing that counts is one's faith, the bourgeois do not enter paradise more quickly than other people" (Miquel, 1976: 158-9). The Vatican retaliated: Erasmus's works were banned and Luther was "declared a heretic, cursed and excommunicated" by Pope Leo X, who also began a large-scale counterattack against heresy (Miquel, 1976: 158-9).

Much to the chagrin of the Church, however, France was seriously affected by the Reformation and became a major breeding ground of rebellion. In 1536 Jean Calvin, the first reformer to write in French, published his Institution de la Religion Chrétienne. Soon afterward a scandal broke out in Paris: placards denouncing the "unbearable abuses of the papal mass" appeared throughout the city and when the French King found one of them hanging on his bedroom door, the repression of the State met that of the Church (Miquel, 1976: 161). "No trouble now or in the future should be given to the clergy", a Royal Edict read, "and none will be allowed to smash or demolish crosses or images and do other scandalous and seditious acts, on pain of death, without hope of grace or remission" (Potter, 1997: 31). Because the defections also came from the inside, another Royal Edict "admonished and exhorted" the French clergy "to work for the order of the Holy Church...so as to return those who are in error to the way of truth" (Potter, 1997: 24).

Although the King tried to stop the propagation of the Reformation and to convert the insurgents by force, he failed, and two centuries of bloody religious wars followed (Yardeni, 1971). From the first protestant massacre in 1523 to the last pastor persecuted in the $18^{\text {th }}$ century, the confrontation between the Catholic and Protestant religions - heightened by the union of Church and State - caused hundreds of thousands of deaths across France (Miquel, 1980). Cities, towns, villages, and even families, were divided and a combination of fear, faith and violence produced terrible excesses on both sides. An exasperated Parliament of Paris deplored the "damned Lutheran sect" and prohibited "under pain of death to read and to ask to read any work in French and Latin containing heretical and erroneous doctrines printed in Geneva or other suspicious cities" (Miquel, 1980: 114). Yet the Reformation had already caused a rupture between modernity and Catholicism; the Pope was no longer the spiritual chief of the Western world, but only of the Roman Church. More importantly, a permanent scar was left on France's national consciousness: religion meant violence and terror, especially when a kingdom sided with a powerful faith and agreed to crush a part of its own population on religious grounds (Miquel, 1980: 22).

\section{The Crisis: Enlightenment, Revolution and 'Concordat'}

\subsection{The Enlightenment}

In the $17^{\text {th }}$ century, an ideological confrontation began to develop between the Enlightenment and the Church in France. This intellectual revolution - brought about by French thinkers such as Descartes, Voltaire, Rousseau, Diderot, d'Holbach and d'Alambert — was to play a crucial role in the genesis of the revolutionary movement of 1789 and was to influence France and the world for centuries to come. As one author underlines, "when the Enlightenment started to foster a marketplace of ideas, it clashed, with an intensity that was specifically French, against the all-powerful Catholic Church, which was united to the absolute monarchy in a ubiquitous alliance" (Scot, 2003: 23).

This conflict between the enlightenment and the Catholic Church was palpable. Descartes's cogito, ergo sum ('I think, thus I exist'; Descartes, 2000: 49) and his exhortation to "never accept anything as true unless your reason has experienced it to be so" was in blatant contradiction with the Church's dictum of crede ut intelligas ('Believe so that you can understand') and the dogma that human reason is inherently fallacious unless supported by unconditional faith (Pena-Ruiz, 2005: 32). "A Master like Jesus who exerts such an authority", the theologians of the Sorbonne insisted, "certainly deserves, in spite of the obscurity of his doctrine, to be believed on His word" (Pena-Ruiz, 2005: 32). Their conclusion was simple: ipso audite, let us not look at the reasons for the truths that He teaches, because all reason exists in the fact that He has spoken.

Les philosophes were particularly harsh with what they saw as the Church's stubbornness in clinging to the Scriptures and in rejecting any scientific discovery at odds with the Bible; as Rousseau put it, "the Church decides that the Church has a right to decide" (Rousseau, 1996: 397). The heliocentric theories of Copernicus, for example, later developed by Galileo and Giordano Bruno, were considered anathema by Rome because they contradicted the holy books and their authors were persecuted. Galileo was imprisoned and his texts banned, while Giordano Bruno was condemned as a heretic by the Venice inquisition and spent eight years in prison before being publicly burned alive in 1600. As Pascal wrote, however, "this will do nothing to prove that the Earth does not move. And if we had constant observations proving that it is the Earth that indeed turns, all men in the world cannot do anything to stop it from turning..." (Pascal, 1954: 897). Pascal was also considered 
"anathema" and his writings were added to the List of Prohibited Books, which was by then becoming a voluminous document. It was only abandoned by the Vatican in 1966 (Pena-Ruiz, 2005: 43).

Yet like most French philosophes, Locke, Bacon and Newton were not against religion per se: their enthusiasm for knowledge and their passion for scientific discovery were not incompatible with God. "Senses, reason and faith have their own objects and certitude," Pascal wrote. "If at issue is a super-natural thing we will not judge it by the senses nor by reason but by the Bible and the decisions of the Church. But if at issue is a point of fact we will have confidence in our senses" (Pascal, 1954: 897). The Enlightenment was nevertheless irreconcilable with the dogmas of the Roman popes and in France it often translated into a broader hostility towards religion as a whole. "It is thought to be pious to look at one's reason and one's own judgement with distrust", Spinoza wrote, "while it is considered impious not to have full confidence in those who conveyed to us the holy books. This is not piety, it is pure idiocy" (Spinoza, 1965: 251) (Note 5).

On the eve of the French Revolution this hostility was so strong, and the reputation of the Church so tarnished, that France had become the avant-garde of anti-Catholic sentiment in Europe. "The mantra about hell and fear is no longer compelling", Jean Delumeau observed (in Ormière, 2002: 23). People stopped being afraid and clergymen started worrying - and rightly so, for violent change was in the air.

\subsubsection{The French Revolution (1789)}

In the centuries-long union of Church and State, the French Revolution stands out as the most traumatic event of all. The substitution in 1789 of the Ancien Régime - a social system whereby nobility and clergy occupied a central place - with a polity of free and equal people, had fundamental consequences for the Catholic Church and its relationship with the State.

The rupture was threefold and generated several revolutions at once. First and foremost, by recognising that "men are born and remain free and equal in their rights" and that "social distinctions can only be based on social utility", the Constituents carried out a democratic revolution that changed the very structure of French society and acknowledged the primacy of the masses over the elites (Mélin-Soucramanien, 2005: 4). Secondly, by proclaiming that "the principle of sovereignty essentially resides in the Nation" and that "no other body nor individual can exercise any authority unless this expressly derives from the Nation", the Assembly realized a secular revolution and acknowledged the sovereignty of the State over the Church (Mélin-Soucramanien, 2005). Thirdly and finally, by declaring that "none should be disturbed because of his opinions, even religious ones, unless their manifestation perturbs the public order established by law", the Constituents generated a civil rights revolution that questioned the pre-1789 order (Mélin-Soucramanien, 2005). While the dogmatic, legal and political union between Church and Kingdom had rendered the idea of freedom of conscience impossible, this changed when a series of decrees recognised the equality of Protestant and Jewish citizens (Scot, 2003: 38).

The logical outcome of this futuristic edifice would have been a complete separation of Church and State. However, revolutions are rarely logical and, in the case of France, the State instead violently tightened its control over the Church, attacking both the temporal and the spiritual authority of the Vatican. Its temporal authority was diminished by abolishing all ecclesiastical privileges and dimes (a tax on revenues that the Church had collected for centuries) and by putting "all Church property at the disposal of the Nation" (Charlier-Dagras, 2002: 55). As one author observed, after losing two of its most important sources of income, "the temporal Church no longer existed" (Scot, 2003: 40). As far as spiritual authority was concerned, the Revolution translated into the triumph of Gallicanism and the State created a 'national religion' independent of papal authority. The Civil Constitution of the Clergy of 1790 is an example of this political will to "francizise" Catholicism and to subordinate the Church to the State: the religious administration was modelled on the French model of public administration, clergymen were paid by the State, they were no longer nominated by Rome but elected by parishioners, and like any other civil servant, they were required to take an oath of allegiance to France (Note 6).

The significance of these changes and their impact on the Church can be gauged by the vitriolic reaction of the Pope. In 1790 Pius VI defined the Revolution "a satanic disorder" (Dansette, 1966: 68), writing that freedom of thought and expression was "a monstrous right" (Scot, 2003: 45) and concluding that the 1789 Declaration of the Rights of Man and of the Citizen was "incompatible with the Catholic tradition" (Scot, 2003: 45). He further called the Civil Constitution "a sacrilegious, heretic, schismatic law" (Beau de Lomenie, 1956: 63) and he prohibited the French Church from reciting the oath; most French clergymen disobeyed, and this conflict produced considerable anti-religious violence.

Following this condemnation of the Revolution, Paris broke diplomatic relations with the Vatican, and a statute declaring recalcitrant priests to be "suspicious people" compelled thirty-thousand of them to leave the country (Scot, 2003: 55). At the same time hundreds of ministers were murdered in several Paris prisons, more than a 
thousand were condemned to death by revolutionary tribunals and two thousand were summarily executed. (Lefebvre, 1932; Cobb, 1975). After the fall of the monarchy, anticlericalism took hold of the masses and the "de-Christianization" movement pervaded France, of murdering priests, violently interrupting celebrations, attacking churches, mocking sacraments, vandalizing sacred objects and defacing temples (Vovelle, 1995, 1988; Van Kley, 1996). Indeed, so irreverent were the protestors that a prostitute was put on the altar of Notre Dame Cathedral. Once again, religion had translated into fighting and bloodshed and this time, State-enforced violence played a significant role.

Thus, the French Revolution had varied effects upon religious freedom. Every society needs some form of spirituality, and in revolutionary France this took the form of a civil religion based on the Universal Declaration of the Rights of Man and of the Citizen (Mornet, 1933). However, things are often different in theory then they are in practice and this was certainly the case in post-1789 France. Indeed, one is left with the impression that, after having wisely decided to part from the Church relatively peaceably with the Declaration, the State somehow changed its mind and attacked it instead (Charlier-Dagras, 2002: 57).

It should also be said that the Catholic hierarchy was not irreproachable either. Its wealth, temporal ambition, dogmatism and authoritarianism - the Inquisition is an early case in point - had consistently pushed the Vatican to adopt an intolerant stance (Note 7). In addition to the above-mentioned condemnations of the Enlightenment and the Revolution by Pope Pius VI, his successor Gregory XVI came to define freedom of the press as "a most terrible, execrable right" and freedom of conscience as a "false and absurd maxim, or rather a delirium" (Scot, 2003: 25); it was, he wrote, "one of the most contagious errors brought about by this absolute and unrestrained liberty that is ruining both Church and State and is spreading everywhere" (Scot, 2003: 25). As for religious freedom, Pope Pius IX enumerated twenty-four "major mistakes of our time" and these included "freedom of conscience, modern civilization and liberalism" (Bruley, 2004: 55). "It is a mistake", he wrote, "to say that every man should be free to embrace and profess the religion that he considers true" (Scot, 2003: 80).

\subsubsection{The 'Concordat' (1801)}

Napoleon, too, proved to be an authoritarian partner for the Church. After the excesses of the Revolution, one of his priorities was to attain religious harmony, and this necessarily meant negotiating with Rome. In 1801 he signed the Concordat with Pope Pius VII, an attempt at compromise that realized an embryonic form of separation whilst giving birth to a religious Restoration. According to this document, while Catholicism was no longer the official religion of France, it remained "the religion of the great majority of French citizens" and one which "French Consuls profess with special attachment" (Bruley, 2004: 46-7). "God save the Republic, God save the Consuls", read the formula that had to be recited "at the end of the divine Mass in all Catholic churches of France" (Bruley, 2004: 48). The Concordat also acknowledged that "the Catholic, apostolic and Roman religion will be freely exercised in France" and that this exercise "will be public" (Bruley, 20094: 48).

Yet this freedom was limited since bishops were nominated by the French government (though the Pope had the right to veto such nominations). In addition, an oath of fidelity to the Nation was required from all bishops and this took 'Gallican' forms: "I swear and promise to God upon the Saint Evangels to remain obedient and faithful to the government established by the Constitution of the French Republic", the oath read. "I also promise not to get involved, participate or join any league or council, either internal or external, that is contrary to public peace; and if, in my dioceses or elsewhere, I learn that something is being plotted against the State, I shall let the Government know" (Bruley, 2004: 48). While Catholicism was given a special place, the existence of the Protestant and Jewish religions was also acknowledged, while all other faiths were merely tolerated (Robert, 1977: 44-7).

This compromise intially satisfied both Rome and Paris, and on Easter Day of 1802 France celebrated the re-establishment of the Catholic religion by re-opening seminaries, renovating churches and indulging in what looked like religious concord. Pius VII even went to Paris, put the Imperial crown on Napoleon's head and solemnly acknowledged his authority. Yet the idyll was short-lived, and in that same year a series of unilateral measures were added to the Concordat which effectively subordinated the Church of France to Napoleon. The document read that "No bulla, briefing, writing, order, mandate, provision or signature, nor any other document from Rome, even if it only concerns individual cases or people, can be received, published, printed or otherwise implemented without the authorization of the government" (Duverger, 1936: 89). In addition, dioceses were ordered to follow only "one liturgy and one catechism" established by Napoleon (Charlier-Dagras, 2002: 65), and religious councils could only meet with the assent of the French government, while seminars had to conform to the "Gallican doctrine" (Scot, 2003: 65). 
Napoleon, by now a veritable Emperor who saw religion as an instrument of power, even tried to force a civic cult of his own personality by imposing a catechism in which he proclaimed himself "sacred by God" and "God's image on Earth" (Scot, 2003: 66). Pius VII did not approve and when he refused to abide by the Concordat, Bonaparte invaded Rome, annexed the pontifical states and incarcerated the Pope, who promptly excommunicated him (Bruley, 2004: 259). The union of the Catholic Church and the French State was clearly in tatters, but it was not yet finished.

\section{The Partition: The Separation of Church and State in 1905}

After the fall of Napoleon in 1815, the Pope was reinstated in Rome and Austria, Prussia and Russia sought to restore the structures of the pre-revolutionary era, where the union of Church and State was at once political (in the implementation of the old church-monarchy union), ideological (in the condemnation of the Revolution and the Enligtenment), and legal (in the abolition of religious freedom and other 'un-Godly' revolutionary rights) (Miquel, 1976: 232). Regime-change gave rise to two Catholic kings (Louis XVIII and Charles X) in France, and a new harmony in the marriage between Church and State: Catholicism once again became the official religion and the clergy became actively involved in public education (Scot, 2003: 128). The two partners, it seemed, were not yet ready to part, and the divorce was postponed.

Nevertheless, the shock of the Revolution and the papal humiliation by Napoleon had altered the relationship and had made the Catholic hierarchy nervous. The Church has a "temporal power that is both direct and indirect", Pope Pius IX wrote in his Syllabus Errorum, and this "gives the Pope and his ministers the right to intervene, including by force, in the definition of laws and customs" (Scot, 2003: 80). The First Vatican Council also made the Pope "infallible" by a "dogma revealed by God" and his judgements "unreformable", whilst also stressing that "any contradiction of this definition is anathema" (Scot, 2003: 82).

However, the events of 1789 could not be erased and in France the bourgeoisie had become fiercely anti-clerical, incensed by the Pope's characterisation of the Revolution as a 'divine punishment' and his condemnation of its principles as "diabolic" (Scot, 2003: 79). Moreover, the alliance of throne and altar led French liberals to see the Church as the ally of absolutism and the enemy of individual freedom. "Man must accept the fact that it is impossible and unnatural to elevate everyone to the same level", the Vatican wrote, and Pope Leon XIII was even more explicit when he declared that "human society as established by God comprises of unequal elements. So the fact that such a society is made up of princes and subjects, masters and proletarians, rich and poor, savants and ignorant, nobles and plebeians, is in accordance with the order established by God" (Pena-Ruiz, 2003: 91).

These ideas were hardly popular at the time. Indeed, the fall of the Empire - and the subsequent birth of the Third Republic - was accompanied by ferocious anti-clerical violence that even took the life of the Archbishop of Paris (Mellor, 1996: 123). The antagonism between Catholics and anti-clericals reached new heights and the religious violence helped to "push Catholics away from the Republican idea"-as an author observed, "the République was the enemy that had to be fought" (Charlier-Dagras, 2002: 76). Thus, by the time the Republicans won the elections in 1876, the separation between Church and State had become an inevitability, and so had the advent of la laïcité.

\subsection{Laïcité in Education}

The first crucial step in this direction was taken in relation to education. Public education in France had long been equated with Catholic education and, given that Catholicism was opposed to the principles of the Enlightenment and the Revolution, schools soon became the battleground between les deux Frances: the clerical and the secular (Coutel, 1991; Lanfrey, 2003). French Prime Minister Emile Combes wrote that "[t]hose who abdicate their personal rights and become entangled to a religious authority do not have the right to teach in public schools, for he who is not free cannot shape free citizens". He concluded that "the state has a duty to protect its youth from their influence" (Scot, 2004: 125) (Note 8). Educational neutrality was nevertheless strongly opposed by the Catholic Church; indeed, the Vatican called it a "pestilence, an inherently false principle and a disastrous one in terms of consequences" (Dansette, 1965: 638). Yet the idea was by then irreversible, as schools had come to symbolize the potential of the République to bring unity, in stark contrast with the divisive effects of sectarian religion. As an intellectual put it at the time, "there must be a place where unity, peace and civil concord are taught which counters the inexorable divisions of faiths and religions" (Quinet, 2001: 76).

With the education laws of the end of the $19^{\text {th }}$ century, tThis place of unity, peace and civil concord was achieved in école laique, as French public shools became free of charge, netural and secular with the education laws of the early 1880s. In addition, all religious symbols were prohibited in schools, the clergy lost its right "of inspection, surveillance and direction" of primary schools (Charlier-Dagras, 2002: 78), and only professional teachers - excluding members of religious groups - were allowed to teach. According to the then-Education 
Minister Jules Ferry, the state had a "right to direct the education of French youth" (Gadille, 1976: 45), to "organize humanity without God and without King" (Charlier-Dagras, 2002: 78) and to obtain the closure of those schools "where a counter-revolutionary discourse is preached" (Gadille, 1976: 54).

This, it should be noted, was not the well-versed 'religious education versus secular education' issue. The purpose of the new legislation, Ferry noted, was to "inculcate French schoolchildren with the religion of their mother country" (Azéma \& Winock, 1978: 81). To instil patriotic sentiments, children were taught to sing nationalistic songs such as Déroulède's Les Chants du Soldat, to read books such as Le Tour de la France de Deux Enfants by Guyau. Put another way, the aim was not only to limit the impact of religion but also to create a national consciousness that united rather than divided - and this national consciousness was to be based upon the principles of the Enlightenment and the Revolution. As one author observed, "the veneration for the mother country appears to be very much like a civil religion that takes the place of the Catholic religion" (Ormière, 2002: 120). This form of national education was extremely successful in creating French citizens and was nothing short of a "Cultural Revolution that translated into the birth, at the beginning of the $20^{\text {th }}$ century, of new French citizens who are more distant from the mentality of their parents and grandparents..." and from their ancestors' religious polarization (Scot, 2003: 114).

\subsection{The Separation of Church and State (1905)}

The separation of Church and State in the educational system soon translated into separation tout court. Indeed, at the beginning of the $20^{\text {th }}$ century, opposition to the Catholic Church had become so strong in France that Prime Minister Waldeck-Rousseau defined the Vatican as "a power no longer hidden", and denounced the "birth, within the state, of a veritable enemy" (Waldeck-Rousseau, 1902: 155). A series of diplomatic incidents with Rome over its unilateral nomination of a number of French bishops, despite the fact that the Concordat required the consent of Paris, further contributed to this heightened tension. A secret letter from the Pope was leaked to the French press, stating that "the Heads of Catholic countries have a duty to show the highest respect to the Supreme Pastor of the Church... and this is particularly the case for the French President, who presides over a Nation that is linked to the Roman Pontificate by the closest traditional relations" (Bruley, 2004: 138). Paris was also "deplored and reproved" by Pius X for its rebelliousness and for the education laws it had recently passed (Scot, 2004: 170).

It is at this point that the separation of Church and State became inevitable. In May 1905, 420 out of 510 French MPs voted in favour of breaking diplomatic relations with Rome, and in September Emile Combes told Parliament that "the religious power of Rome has blatantly torn the Concordat and I, for one, have no intention of repairing it. The only path available to the two conflicting powers is the same one available to a couple in a crisis: divorce, and preferably divorce by consensus" (Scot, 2004: 174).

After fifteen centuries of unholy marriage, and after several failed attempts, the divorce was finally enacted in December 1905 when the Law of Separation between Church and State was passed (Note 9). "The Republic does not recognize, pay or subsidize any religion", Article 2 reads. The Catholic Church was no longer granted official recognition because no religion was officially recognized. Consequently, Catholic priests were no longer paid by the State (Article 2) except for those services which were necessary to "ensure the free exercise of religion in public establishments" such as schools, hospices, prisons, etc. (Article 1).

Despite the turbulence surrounding its establishment, the 1905 statute was a compromise that gave pre-eminence to religious freedom and expression: all faiths were encouraged to choose their own dignitaries, establish their own sacred buildings and organize their own administrative structures because, as one MP observed at the time, only in this way will "religions gain in freedom and the State in legitimacy" (Bruley, 2004: 14). This was a momentous event in the history of France, and it had been fifteen centuries in the making.

\subsection{Rome Rejects (1906) Then Finally Accepts (1924) Laïcité}

However, this separation was far from uncontested; indeed, the acrimonious nature of the divorce more than equaled that of the marriage itself. While the Protestant and Jewish religions declared themselves "ready to accept with confidence the Separation", the Vatican reacted in fury (Scot, 2004: 212). Pius X had already made it clear in 1903 that "the Pope, by virtue of the task assigned to him, absolutely cannot separate political affairs from faith and tradition" (Bruley, 2004: 117). The papal bulla Vehementer Nos of 1906 confirmed this stance, condemned the idea of separation as "a very clear negation of the supernatural order" and attacked the French statute. "By virtue of the supreme authority that God has conferred upon me", he wrote, "I condemn the law voted in France on the separation of Church and State as deeply injurious to God and I denounce it and condemn it as severely dangerous for the dignity of this apostolic seat, for myself, for the clergy and for the entirety of French Catholics" (Scot, 2004: 275). Shortly afterwards a second bulla, Gravissimo Offici (1906), prohibited the 
French clergy from complying with the law and one year later a third document, Une Fois Encore (1907), stated that "it is God that the French Government wants to efface from the human heart and spirit" (Scot, 2004: 296).

While this situation caused serious religious incidents in France, the much-feared schism did not materialize and in 1924 the Vatican accepted the French law with the bulla Maximam Gravissimamque. As for the general mission of the Catholic Church, it was only in 1962 that Rome reversed its position and acknowledged that "the Church, because of its role and competence, is separated from the political community and is not linked to any political system" (Bruley, 2004: 429-432). After fifteen centuries of close association, thousands of deaths and much religious violence, the union was truly over.

\section{Conclusion: What Place for Religion in Modern France?}

The history of France is the history of a ruthless competition between spiritual and secular power. Kings and popes distrusted each other but they both had something that the other wanted-military dominance in the first case, spiritual supremacy in the second. Their quest for domination pushed them into an unhealthy marriage, devoid of love but full of violence. Conceived by the Enlightenment, attempted and immediately aborted by the Revolution, and finally realized by the République, the separation was traumatic and took centuries to materialize. In the end, it was the French State that had the courage and determination to part from the Church, and by the time the separation finally happened, the country had lost confidence in religion in general. The latter was no longer associated with freedom, and had not been for a long time, instead having become a synonym for despotism and violence.

Given the strong association between laïcité and république, it is not surprising that modern France reveres the former and gives it a high constitutional value (Mélin-Soucramanier, 2005: 27). It is also unsurpring that, in contemporary France, the separation of Church and State is unanimously regarded to be the turning point in establishing a key principle of the Nation. "Separation has never united us as much as today", one author observed, and "every religion, including Catholicism...claims a place in the history of French laïcite" (Bruley, 2004: 463). But the exceptionally violent religious history of France does seem to have left a mark on its national consciousness, one that reads: 'Religion divides, la République unites.'

Perhaps it is this message that the French unconsciously convey when they proudly declare their distinctive detachment from religion. Perhaps it is because of this message that French laïcité "denies to religion any official role in civil society" and is reluctant to admit it—or, more accurately, is reluctant to formally admit it-as a visible presence in the public space (Gaillard in Scot, 2003: 20). And perhaps it is this message that contributes to ensuring that the French separation is something more than an institutional, horizontal division; it is rather something akin to a vertical partition where la République occupies not only a different but also a higher place than religion (Barbier, 1996: 69). The fact that religion has historically been not only controversial but also disruptive was perhaps best conveyed by Adolphe Thiers, one of the fathers of modern France, when he said that "la République is the system that divides us the least" (Ormières, 2002: 106). What is sure is that France has been less divided under la République than it ever was under the union of Church and State.

\section{References}

Autrand, F. (1974). Pouvoir et Société en France. Paris: Presses Universitaires de France.

Azéma, J. P., \& Winock, M. (1978) La Troisième République. Paris: Calmann-Lévy.

Baigent, M., \& Leigh, R. (2004) L'Inquisizione: Persecuzioni, Ideologia e Potere. Milan: Saggiatore.

Barbier, M. (1996). La Laïcité. Paris: L'Harmattan.

Beau de Lomenie, E. (1956). L'Église et l'État, Un Problème Permanent. Paris: Fayard.

Benimeli, J. A. F. (1976). Masoneria, Iglesia e Ilustración. Madrid: Plan.

Bruley, Y. (2004). La Séparation des Églises et de l'État: Les Textes Fondateurs. Paris: Perrin.

Burman, E. (1992). The Inquisition: The Hammer of Heresy. New York: Dorset.

Cameron, E. (1991). The European Reformation. Oxford: Oxford University Press.

Charlier-Dagras, M. D. (2002). La Laïcité Française à l'Epreuve de l'Intégration Européenne. Paris.

Cobb, R. (1975). La Protestation Populaire en France. Paris: Calmann-Lévy.

Cornec, J. (1965). Laïcité. Paris: Sudel.

Coutel, C. (1991). La République et l'École: Une Anthologie. Paris: Pocket.

Crouzil, L. (1954). Le Régime Légal du Culte Catholique. Paris: Action Populaire. 
Dansette, A. (1966). Histoire Religieuse de la France Révolutionnaire. Paris: Flammarion.

De Tocqueville, A. (1967). L'Ancien Régime et la Révolution. Paris: Gallimard.

Debidour, A. (1898). Histoire des Rapports entre l'Église et l'État en France de 1789 à 1870. Paris: Alcan.

Delumeau, J. (1988). Naissance et Affirmation de la Réforme. Paris: Nouvelle Clio.

Descartes, R. (1996). Discours de la Méthode. Paris: Flammarion.

Descartes, R. (2000). Les Passions de l'Âme. Paris: Flammarion.

Duverger, J. B. (1836). Collection Complète de Lois depuis 1788. Paris: Guyot Scribe.

Estep, W. R. (1986). Renaissance and Reformation. New York: Eerdmans.

Gadille, J. (1976). Pensée et Action Politique des Evêques Français. Paris: Hachette.

Goubert, P. (1984). Initiation à l'Histoire de la France. Paris: Tallandier.

Gregoire, A. (1988). Essai sur la Régénération Physique, Morale et Politique des Juifs. Paris: Stock.

Gui, B. (1998). Il Manuale dell'Inquisitore. Milan: Gallone.

Haussonville, J. (1906). Après la Séparation. Paris: Perrin.

Kingdon, R. M. (1956). Geneva and the Coming of the Wars of Religion in France. Geneva: Dronz.

Lambert, F. (2003). The Founding Fathers and the Place of Religion in America. Princeton: Princeton UP.

Lanfrey, A. (2003). Sécularisation, Séparation et Guerre Scolaire. Paris: Cerf.

Le Monde des Religions. (2005). Pourquoi le XXI Siècle Est Religieux. Paris: Éditions du Monde.

Leclerc, J. (1988). Histoire de la Tolérance au Siècle de la Réforme. Paris: Albin Michel.

Lefebvre, G. (1932). La Grande Peur. Paris: SEDES.

LeGoff, J. (1996). Saint Louis. Paris: Gallimard.

MacCulloch, D. (2003). The Reformation: A History. New York: Penguin.

Madelin, L. (1938). Histoire du Consulat et de l'Empire. Paris: Hachette.

Maudit, E. M., \& Maudit, J. (1984). La France Contre la France. Paris: Plon.

Mélin-Soucramanien, F. (ed.) (2005). Constitution de la République Française. Paris: Dalloz.

Mellor, A. (1996). Histoire de l'Anticléricalisme Français. Paris: Marne.

Miquel, P. (1976). Histoire de la France. Paris: Fayard.

Miquel, P. (1980). Les Guerres de Religion. Paris: Fayard.

Mornet, D. (1933). Les Origines Intellectuelles de la Révolution Française. Paris: Armand Colin.

Ormières, J. L. (2002). Politique et Religion en France. Brussels: Complexe.

Pascal, B. (1954). Euvres Complètes. Paris: Gallimard.

Pelletier, D. (1997). Les Catholiques en France Depuis 1815. Paris: La Découverte.

Pena-Ruiz, H. (2003). La Laïcité:Textes Choisis. Paris: Flammarion.

Pena-Ruiz, H. (2005). Dieu et Marianne: Philosophie de la Laïcité. Paris: Presses Universitaires de France.

Potter, D. (ed.) (1997). The French Wars of Religion: Selected Documents. London: Macmillan.

Quinet, E. (2001). L'Einsegnement du Peuple. Paris: Hachette.

Robert, J. (1977). La Liberté Religieuse et le Régime des Cultes. Paris: Presses Universitaires de France.

Rousseau, J. J. (1970). CEuvres Politiques. Paris: Gallimard.

Rousseau, J. J. (1996). Émile ou l'Éducation. Paris: Flammarion.

Royer, J. P. (1969). L'Église et le Royame de France au XIVème Siècle. Paris: LGDJ.

Salton, H. (2012). A Godless Constitution? Faith, Politics and Speech in the Bill of Rights of the United States. International Law Research, 1(1).

Scot, J. P. (2005). L'État Chez Lui, l'Église Chez Elle: Comprendre la Loi de 1905. Paris: Seuil.

Spinoza, B. (1965). Traité Théologico-Politique. Paris: Flammarion. 
Sumption, J. (1978). The Albigensian Crusade. London: Routledge.

Sutherland, N. M. (1984). Princes, Politics and Religion. London: Hambledon.

Tackett, T. (1986). La Révolution, l'Église, la France: Le Serment de 1789. Paris: CERF.

Truchet, J. (1966). Politique de Bossuet. Paris: Armand Colin.

Van Kley, D. (1996). The Religious Origins of the French Revolution. New Haven: Yale University Press.

Vovelle, M. (1985). La Mentalité Révolutionnaire: Société et Mentalités. Brussels: Complexe.

Vovelle, M. (1988). La Révolution contre l'Église: De la Raison à l'Etre Suprême. Brussels: Complexe.

Waldeck-Rousseau, R. (1902). La Défense Républicaine. Paris: Eugène Fasquelle.

Yardeni, M. (1971). La Conscience Nationale en France pendant les Guerres de Religion. Paris: Louvain.

Yovel, Y. (1991). Spinoza et Autres Hérétiques. Paris: Éditions du Seuil.

\section{Notes}

Note 1 . Surveys suggest that despite a resurgence of spirituality, French people are increasingly detached from religion. Atheists have increased from $8 \%$ of the population in 1970 to $25 \%$ in 1997 (Ormières, 2002: 216); young people who "believe in God" decreased from 79\% in 1977 to $46 \%$ in 1997 (Ibid.); a majority of the population thinks that religion is not important (57\% against 41\%) (Le Monde des Religions, 2005: 41); and the number of self-proclaimed Catholics is falling so rapidly that "the possibility of a disappearance of Catholicism can no longer be excluded" (Ormières, 2002: 215). This article is a revised version of my Veiled Threats? Islam, Headscarves and Religious Freedom in America and France (2008).

Note 2. The term laïcité is untranslatable into English and cannot be conveyed by the words secularism or neutrality without losing much of its spirit. As one author puts it, "Laïcité cannot be defined, it can only be lived" (Cornec, 1965: 494).

Note 3. Emperor Theodosius called Christianity "the religion that the divine apostle Peter has transmitted to the Romans" (Pena-Ruiz, 2003: 22).

Note 4 . The Protestant Reformation was a $16^{\text {th }}$ century movement aimed at reforming the Catholic Church from the perceived corruption, 'false doctrines' and 'malpractices' of Rome, particularly concerning the sale of indulgences. See e.g. Cameron, 1991; MacCulloch, 2003; and Estep, 1986.

Note 5. Spinoza was also disliked by the Jewish authorities: "By virtue of the Holy Decrees and the words of Saints", the Amsterdam Synagogue leadership wrote, "we ban, exclude, curse and declare anathema Baruch de Spinoza with all the curses described in the law. Cursed be he during the day, and cursed be he during the night, cursed be he when he goes to bed and cursed be he when he wakes up, when he leaves and when he arrives" (Yovel, 1991: 19).

Note 6. "I swear to be faithful to the Nation, to the law and to the King", the pledge read, "and to uphold to the best of my abilities the Constitution decided by the Assembly and accepted by the King" (Tackett, 1986, 35).

Note 7. Few institutions illustrate the perverse effects of the connection between Church and State more effectively than the Inquisition. Established in 1233 by Pope Gregory IX, it was directly managed by Rome with the purpose of limiting the spread of ideas considered subversive and heretical, but it happily relied on secular justice to enforce its death sentences, thus effectively using the State for its repressive purposes. Inquisitors were given by papal order "the legal authority to condemn those suspected of heresy without any possibility of appeal, and therefore to all effect and purposes to pronounce summary condemnations to death" (Baigent \& Leigh, 2004: 39). As one inquisitor wrote in 1578 , "we must remember that the main purpose of the trial and execution is not to save the soul of the accused but to obtain the public good and permeate others with fear" (Baigent \& Leigh, 2004: 86). Torture was performed on the grounds that, as St Augustine had written, "there is an unjust form of persecution (the one performed against the Church by impious people) and there is a just form of persecution (the one performed by the Church against impious people). The Church persecutes out of love while impious people do so out of cruelty" (Leclerc, 1988: 85).

Note 8. For a vitriolic attack against Catholic education, see the following passage by Victor Hugo: "The history of the Church is indeed part of the history of human progress, except that it is written in the reverse. It opposed everything. It is the Church that beat up Prinelli for saying that the stars were not to fall. It is the Church that persecuted Campanella for saying that the number of worlds was finite. It is the Church that mistreated Harvey for proving that the blood circulated. Quoting Josué, it imprisoned Galileo; quoting Saint Paul, it incarcerated 
Christopher Columbus. To discover the law of the universe was an impiety; to discover a new world was heresy. It was the Church that declared Pascal anathema on ground of religion, Montaigne on ground of morals, and Molière on grounds of both religion and morals. And you want to be the masters of education!" (Hugo cited by Pena-Ruiz, 2003: 48).

Note 9. In 1897 the laïcité principle was defeated by 310 votes against 138; in 1898 by 311 to 183 , in 1899 by 329 to 179 and in 1900 by 315 to 194 (Crouzil, 1954: 13-14). 